\title{
THE VOLUME WEIGHT OF THE ORGANIC MATTER IN THE PLOUGH LAYER OF PEAT LANDS CULTIVATED BY DIFFERENT METHODS
}

\author{
YRJÖ PESSI \\ Society of Peat Cultivation, Experimental Station Leteensuo
}

Received September 22, 1961

It is a well-known fact that the physical properties of the substrate influence the growth of plants, and pains are therefore taken in crop husbandry to retain the favourable physical properties of the soil, or to improve them if necessary. In organogenic soils the quality of the organogenic matter exerts a remarkable influence on the physical properties. The microorganisms in the soil may produce changes in the organogenic matter, and again, the activity of the microorganisms is affected by the cultivation measures, e.g. fertilizing and soil improvement. It is therefore to be expected that changes in the physical constitution of the soil will occur in the course of its agricultural use. Furthermore, cultivation adds plant residues and root substance to the soil. Different cultivation techniques may also produce different changes in the soil.

The purpose of this investigation is to report on the volume weight of the organic matter in the plough layer of peat lands today as the outcome of agricultural use according to different cultivation techniques through several decades. At the same time it proposes to study whether soil improving treatment and fertilization have affected the volume weight.

\section{Material and methods}

The material of the investigation was collected in 1960 .

The material was chosen from the long-term soil improvement and fertilizing tests in progress at the experimental stations of Ruukki, Leteensuo and Tohmajärvi. An investigation concerning the ash content of the plough layer has previously been published on the basis of the same material, and the tests in question have been described in detail (2). It will suffice in this connection to refer to the said work, which also contains a description of the methods of soil sampling and sample handling. 
The volume weight of the soil was determined by means of the method employed by PJavtshenko $(3,4)$. The dried peat was ground and passed through a sieve of $0.5 \mathrm{~mm}$ mesh. The powdered peat was carefully mixed and samples were taken for the moisture and ash content determinations. For determination of the volume weight $10 \mathrm{~cm}^{3}$ of the peat was poured into a measuring glass, tapping the bottom of the glass against a resilient base until the peat had settled to an invariable volume. In this way the glass was always filled to the $10 \mathrm{~cm}^{3}$ index line. Subsequently the peat was compressed with the aid of a piston under $1 \mathrm{~kg} / \mathrm{cm}^{2}$ pressure.

For the determination of the moisture content the peat sample was kept 24 hours at $+110^{\circ} \mathrm{C}$. The ignition residue, in per cent of the dry substance, was taken to represent the ash percentage.

The obtained volume weight was converted to the volume weight of the ashfree, completely dry peat. Two different volume weights of the ash were used in the calculations by which the volume of the ash constituents was accounted for. When sand had been used as a soil improving agent, one value was employed, and another when the soil had been improved by an addition of clay. The volume weights of sand and clay, respectively, were studied with the aid of samples taken at Leteensuo from the exact sites where the soil improving agents were originally obtained. The volume weight 1.5 was thus found for the ash constituents of sand, and 1.2 for those of clay. PJavtshenko (3), too, has used 1.2 for the volume weight of clay ashes. In cases where no soil improving agent had been added, the volume weight of the ashes was assumed to be 1.2.

The following preliminary experiment was carried out in order to find out whether an error is caused by mineral soil added as a soil improving agent when the volume weight is converted to the volume weight of ash-free peat. Poorly humified Sphagnum peat with no previous additions of mineral soil was given increments of sand or clay, so that a different ash content of the peat was obtained in the different samples. The volume weight was then determined for the different peat and mineral soil mixtures. When the figures had been converted to represent the volume weight of the ash-free, dry peat on the basis of the above-mentioned volume weights of sand and clay, no systematic variation of this value with increasing ash content was noted. The inference was made that the method could be applied in this investigation. However, the observation was made that the increase of the ash content caused by an addition of mineral soil may result in a greater dispersion of the ultimate volume weight values, owing to the fact that the mineral soil may be unevenly distributed in the peat sample in spite of careful mixing.

\section{Results}

The results of the investigation are shown in Tables $1-7$. As the volume weights were determined separately for the separate test replicates, the results could be subjected to analysis of variance and to the t-test. This was done in order to find out whether the soil improving treatment and fertilization have also affected the volume weight. 
A study of the volume weight figures reveals that they are generally in the same order of magnitude which is usually given for the widest range of variation for the different peat groups (5). It should be kept in mind that the volume weight of peat shows a fairly distinct variation with the degree of humification $(1,4)$.

Table 1. Volume weight of organic matter in plough layer found in different treatments in soil improvement and fertilizing test on fen land at Leteensuo. Experiment and cultivation started in 1910.

\begin{tabular}{|c|c|c|c|c|c|}
\hline \multirow{2}{*}{$\begin{array}{l}\text { Mineral soil } \\
\text { addition, } \\
\mathrm{m}^{3} \text { per hectare }\end{array}$} & \multicolumn{3}{|c|}{ Volume weight } & \multirow{2}{*}{$\begin{array}{l}\text { Increase caused } \\
\text { by soil impro- } \\
\text { ving }\end{array}$} & \multirow{2}{*}{$\begin{array}{l}\text { Joint } \\
\text { effect }\end{array}$} \\
\hline & Unfertilized & Fertilized & Mean & & \\
\hline 0 & 0.367 & 0.411 & 0.389 & - & - \\
\hline 200 clay & 0.396 & 0.425 & 0.410 & +0.021 & -0.015 \\
\hline 200 sand & 0.360 & 0.413 & 0.386 & -0.003 & +0.009 \\
\hline 400 clay & 0.394 & 0.412 & 0.403 & +0.014 & -0.026 \\
\hline 400 sand & 0.396 & 0.406 & 0.401 & +0.012 & -0.034 \\
\hline 600 clay & 0.369 & 0.372 & 0.370 & -0.019 & -0.041 \\
\hline 600 sand & 0.412 & 0.413 & 0.412 & +0.023 & -0.043 \\
\hline 800 clay & 0.380 & 0.410 & 0.395 & +0.006 & -0.014 \\
\hline 800 sand & 0.415 & 0.450 & 0.432 & +0.043 & -0.009 \\
\hline Mean & 0.388 & 0.412 & - & - & - \\
\hline \multirow[t]{4}{*}{ F values: } & Mineral soil & $9.90 * * *$ & & & \\
\hline & Fertilizing & $43.77 * * *$ & & & \\
\hline & Joint effect & $3.61^{*}$ & & & \\
\hline & Fertilizing & $4.478 * * *$ & & & \\
\hline
\end{tabular}

Table 2. Volume weight of organic matter in plough layer found in different treatments in claying and fertilizing test on fen land at Leteensuo. Experiment and cultivation started in 1921.

Fertilizing

Volume weight

Unclayed

Clayed Mean Difference between
the PK and P plots

\begin{tabular}{lllll}
\hline P & & & & \\
PK & 0.302 & 0.323 & 0.312 & + \\
P2K & 0.313 & 0.343 & 0.328 & 0.016 \\
P3K & 0.343 & 0.355 & 0.349 & 0.037 \\
P4K & 0.330 & 0.330 & 0.330 & +0.018 \\
Mean & 0.321 & 0.338 & 0.329 & -0.017 \\
F values: Claying & 0.322 & 0.338 & - & \\
Fertilizing & $4.63^{*}$ & & \\
Joint effect & $0.81^{\circ}$ & & \\
t value, Claying & $3.242^{*}$ & &
\end{tabular}


Table 3. Volume weight of organic matter in plough layer found in different treatments in claying and fertilizing test on fen land at Ruukki. Cultivation started in 1932.

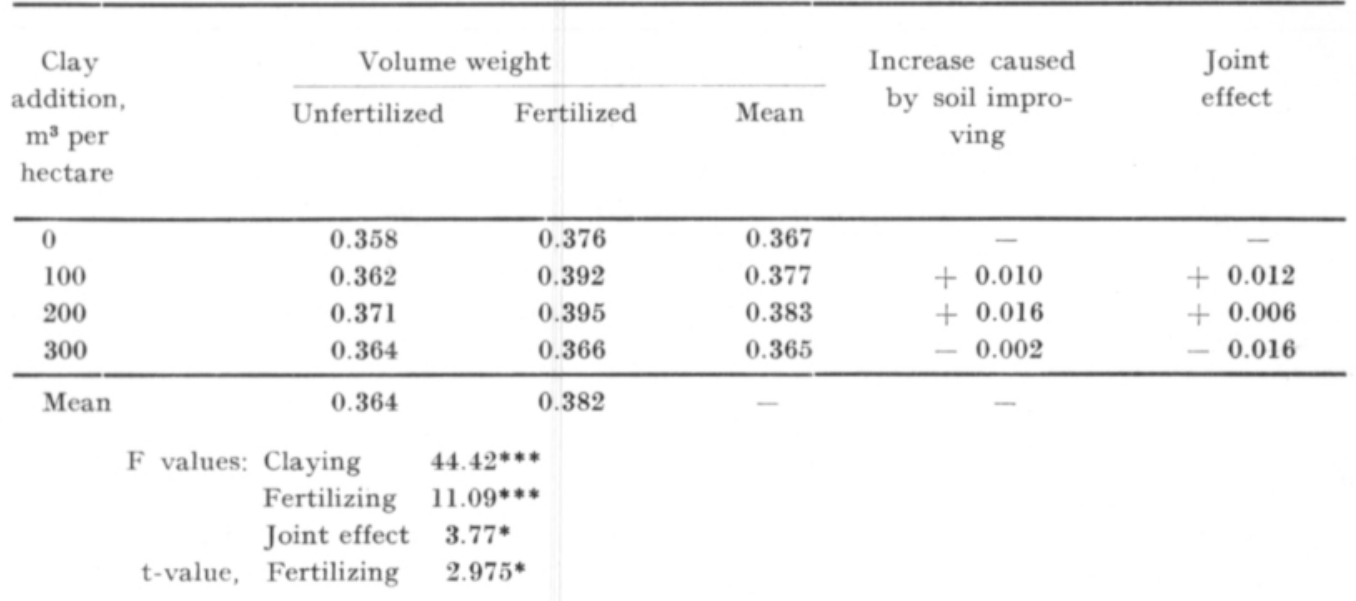

However, it should be noted in comparing the volume weight values that the method of investigation may affect the results, and the methods were not identical. Moreover, peat in a natural state contains ash, usually less than $10 \%$ but still enough to increase the volume weight, and the figures given here refer expressly to ash-free peat. As no volume weight determinations of the peats in the experimental area had been made before they were brought into cultivation, it is impossible to say to what extent cultivation of the soil has influenced the volume weight of the organic constituent. However, the volume weight of virgin Sphagnum peat was determined on a site adjacent to the Sphagnum peat tests of Leteensuo, and the value 0.193 was found. It is seen from the figures presented in Tables 5 and 6 that the volume weight of the organic matter has increased in the course of decades due to the cultivation measures.

The $\mathrm{F}$ - and t-values given in connection with the results serve as further indication of the fact that the method of cultivation affects the change of volume weight. The volume weight has usually increased as a consequence of fertilizing, liming and addition of mineral soil, except in the test at Tohmajärvi (Table 4). The results in the latter instance can probably be explained by the circumstance that the entire test area must have had a very high ash content even originally, since the ash content of the peat in the plots without treatment was more than $40 \%$ according to the present examination (2). The effect of the soil improvement and fertilizing would thus not have manifested itself as a further increase of the ash content.

The present results are believed to justify the conclusion that certain methods of cultivation are more conducive to humification of the peat than others. The peats investigated in this instance were, however, no longer unadulterated as the soil was admixed with plant residues and root substance, and the above-mentioned conclusion cannot be drawn, without reservations, from the volume weights alone. However, it seemed desirable to investigate on the basis of one of the Sphagnum bog 
Table 4. Volume weight of organic matter in plough layer found in different treatments in soil improvement and fertilizing test on fen land at Tohmajärvi. Cultivation started in 1932, experiment started in 1935 .

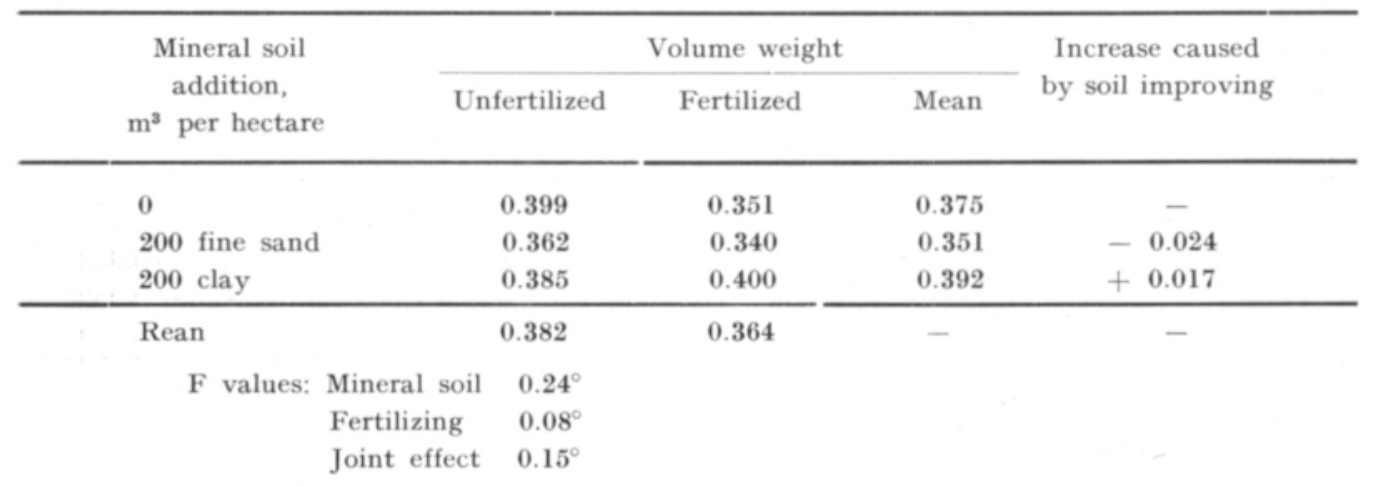

Table 5. Volume weight of organic matter in plough layer found in different treatments in liming and claying test on Sphagnum bog at Leteensuo. Cultivation started in 1921, experiment started in 1923.

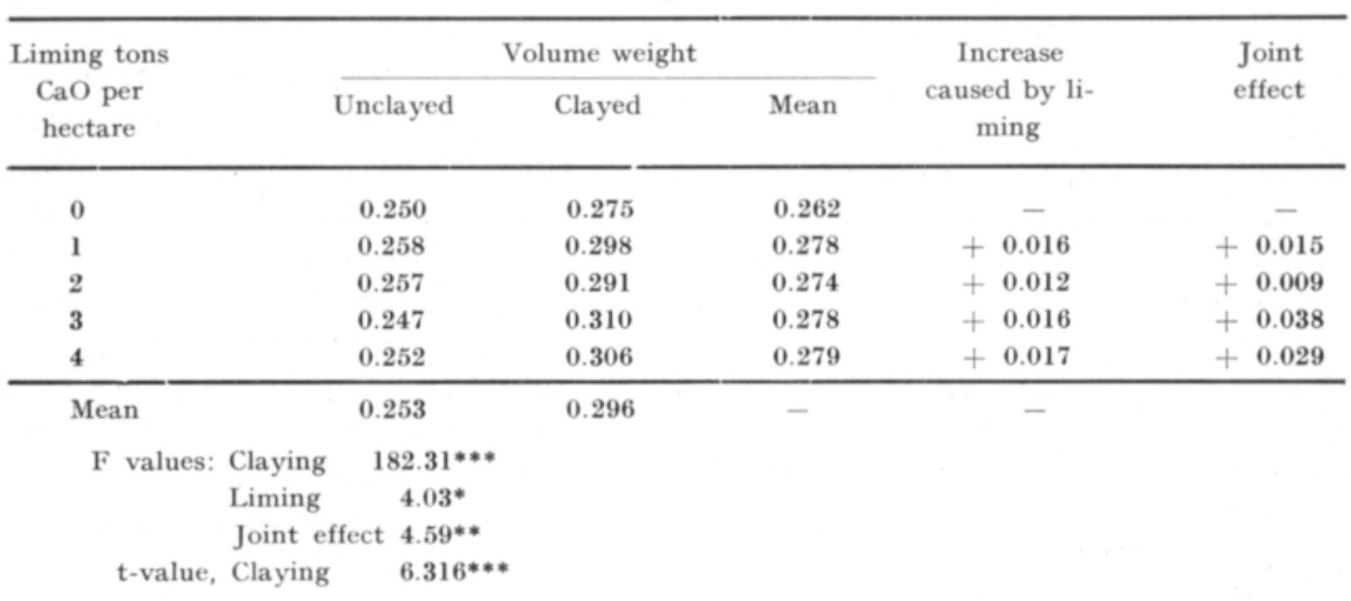

Table 6. Volume weight of organic matter in plough layer found in different treatments in sand addition claying and liming test on Sphagnum bog at Leteensuo. Experiment and cultivation started in 1932.

\begin{tabular}{|c|c|c|c|c|}
\hline \multirow{2}{*}{$\begin{array}{l}\text { Mineral soil } \\
\text { addition } \mathrm{m}^{3} \\
\text { per hectare }\end{array}$} & \multicolumn{3}{|c|}{ Volume weight } & \multirow{2}{*}{$\begin{array}{c}\text { Increase caused } \\
\text { by soil impro- } \\
\text { ving }\end{array}$} \\
\hline & Unlimed & Limed & Mean & \\
\hline 0 & 0.198 & 0.225 & 0.211 & - \\
\hline 200 sand & 0.190 & 0.244 & 0.217 & +0.006 \\
\hline 400 sand & 0.165 & 0.211 & 0.188 & -0.023 \\
\hline 200 clay & 0.209 & 0.215 & 0.212 & +0.001 \\
\hline 400 clay & 0.210 & 0.236 & 0.223 & +0.012 \\
\hline Mean & 0.194 & 0.226 & - & - \\
\hline F values: Liming & $19.4^{* * *}$ & & & \\
\hline Mineral soil & $4.8^{* *}$ & & & \\
\hline Joint effect & $0.2^{\circ}$ & & & \\
\hline t-value, Liming & $3.609 * *$ & & & \\
\hline
\end{tabular}


tests at Leteensuo whether the shrinkage of the peat varies according to the volume weight of the peat. Fleischer (ref. Valmari, p. 223), for instance, has observed that peat shrinks the more, the higher its degree of humification, or, in other words, the higher its volume weight, taking the same type of peat. The investigations were made by taking ten peat samples each from a clayed and unclayed strip (test reported in Table 5) into cylinders of $16.0 \mathrm{~cm}$ diameter and $9.3 \mathrm{~cm}$ height. Five samples each were taken from both strips at points which had been watered close to saturation point shortly before. The shrinkage of the peat could thus be followed with two series of samples having different initial moisture content. The samples were left to dry for several weeks at room temperature. They were weighed before and after drying. Furthermore, moisture determinations were made after conclusion of the drying period, and the amount of shrinkage of the peat in the sampling cylinder was measured. The results can be seen in Table 8 , in which the t-test has been applied. The figures reveal a distinctly greater shrinkage of the clayed peat. It is likely that a different degree of humification is responsible for this.

The values of the volume weight of the organic matter in the plough layer of cultivated peat lands reported above seem to indicate that the volume weight

Table 7. Volume weight of organic matter in plough layer found in different treatments in soil improvement and fertilizing test on Sphagnum bog at Ruukki. Cultivation started in 1920, test started in 1929.

\begin{tabular}{|c|c|c|c|c|c|}
\hline \multirow{2}{*}{$\begin{array}{l}\text { Soil } \\
\text { improving } \\
\text { treatment }\end{array}$} & \multicolumn{3}{|c|}{ Volume weight } & \multirow{2}{*}{$\begin{array}{c}\text { Increase caused } \\
\text { by soil } \\
\text { improving }\end{array}$} & \multirow{2}{*}{$\begin{array}{r}\text { Joint } \\
\text { effect }\end{array}$} \\
\hline & Unfertilized & Fertilized & Mean & & \\
\hline None & 0.374 & 0.355 & 0.364 & - & - \\
\hline Claying & 0.401 & 0.366 & 0.383 & +0.019 & -0.016 \\
\hline Liming & 0.386 & 0.385 & 0.385 & +0.021 & +0.018 \\
\hline Claying and liming & 0.391 & 0.403 & 0.397 & +0.033 & +0.031 \\
\hline Mean & 0.388 & 0.377 & - & - & - \\
\hline $\begin{array}{r}\text { F values: Soil im } \\
\text { Fertilizi } \\
\text { Joint ef }\end{array}$ & $\begin{array}{lr}\text { provement } & 5.9 \\
\text { ag } & 4.4 \\
\text { fect } & 6.2\end{array}$ & & & & \\
\hline
\end{tabular}

Table 8. Mean shrinkage of Sphagnum peat after evaporation of $0.1 \mathrm{~g}$ water from $1 \mathrm{~cm}^{3}$ peat. Peat derived from a liming and claying test at Leteensuo.

Water in $1 \mathrm{~cm}^{3}$ peat prior to evaporation, $\mathbf{g}$

\begin{tabular}{lcc} 
& Shrinkage, \% \\
\hline Clayed & Unclayed & Difference
\end{tabular}

P-

value

\begin{tabular}{rlllll}
\hline & & & & \\
& 0.79 & 6.76 & 5.66 & 1.10 & $<01$ \\
0.44 & 9.32 & 7.67 & 1.65 & $<0.05$ \\
\hline Mean 0.61 & 8.04 & 6.67 & 1.37 &
\end{tabular}


of the organic matter increases in the course of continued cultivation and that also the method of cultivation is significant in this respect. It has already been observed in a previous investigation (2) that also the ash content of the peat increases as a result of cultivation; it was furthermore noted in the same connection that an increase of the ash content may contribute to a change in which the peat land gradually loses its inherent character and begins to resemble humous soil. The present results, again, show that the increase in the volume weight of the organic matter as a consequence of continued cultivation is probably another factor causing a gradual transformation of peat land to a greater resemblance of humous soil.

\section{Conclusions}

The investigation is a report of the results from determinations of the volume weight of the organic matter in the plough layer of cultivated peat lands. They are believed to justify the following conclusions.

As a consequence of continued cultivation through several decades, the volume weight of the organic matter in the plough layer increases. Owing to the fact that cultivation also adds plant residues and root substance to the soil of the plough layer, this increase cannot be positively attributed to the favourable effect of the cultivation measures on the humification of the peat alone, though this effect is certainly thought to be at least partially responsible. The increase of the volume weight is also thought to be one of the reasons why peat lands in the course of continued cultivation gradually evolve a closer resemblance to humus soil.

The cultivation methods influence the change in volume weight of the organic matter. Fertilizing, liming and addition of mineral soil for soil improvement usually produce an increase in the volume weight.

Acknowledgements. The present investigation was supported by a grant from The Finnish Natural Resources Research Foundation (Suomen Luonnonvarain Tutkimussäätiö). I wish to acknowledge this grant with sincere gratitude.

\section{REFERENCES}

(1) KaIlA, A. 1956. Determination of the degree of humification in peat samples. Selostus: Turpeen maatumisasteen määrittäminen. Maat.tiet. aikak. 28: 18-35.

(2) Pessi, Y. 1961. On the ash content of the plough layer of peat lands cultivated by different methods. Selostus: Viljeltyjen turvemaiden muokkauskerroksen tuhkapitoisuudesta. Ibid. 33: $215-222$.

(3) Pjavtshenko, H. 1958. Turpeen maatumisasteen määrittely (Finnish translation).

(4) Sarasto, J. 1960. Turpeen maatuneisuuden määrittämisestä. v. Postin maatumisasteen ja Pjavtshenkon maatumisprosentin vertailu. Referat: Zur Bestimmung der Zersetzung des Torfes. Ein Vergleich des Zersetzungsgrades v. Posts mit dem Zersetzungsprozent des Pjavtshenkos. Acta forest. fenn. $71^{2}, 1-16$.

(5) TuorilA, P. 1928. Wirkung der Kalziumkarbonat- und Schwefelsäurezugaben auf die Azidität von verschiedenen Torfarten. S. suovilj.yhd. tiet. julk. 8: 1-75.

(6) Valmari, J. 1938. Maanviljelyskemia. Porvoo. 324 p. 
S E L O T U S :

\title{
VILJELTYJEN TURVEMAIDEN MUOKKAUSKERROKSEN ORGAANISEN AINEEN TILAVUUSPAINOSTA
}

\author{
YRJö PESSI
}

\section{Suoviljelysyhdistys, Leteensuon koeasema}

Tutkittiin viljeltyjen turvemaiden muokkauskerroksen orgaanisen aineen tilavuuspainoa. Tutkimusaineisto kerättiin Leteensuon, Tohmajärven ja Pohjois-Pohjanmaan koeaseman pitkäaikaisista maanparannus- ja lannoituskokeista.

Tulosten mukaan vuosikymmeniä jatkuneen viljelyn vaikutuksesta muokkauskerroksen orgaanisen aineen tilavuuspaino suurenee. Johtuen siitä, että viljelyn yhteydessä sekoittuu kasvien jätteitä ja juurimassaa muokkauskerrokseen, ei voida päätellä, aiheutuuko tilavuuspainon suureneminen yksinomaan viljelytoimenpiteiden turpeen humifioitumista edistävästä vaikutuksesta, mutta ainakin osittain lienee kysymys juuri tästä vaikutuksesta. Tilavuuspainon kasvu lienee myös eräs syy turvemaiden muuttumiseen aikaa myöten viljelyn jatkuessa multamaita muistuttaviksi.

Viljelymenetelmällä on vaikutusta orgaanisen aineen tilavuuspainon muuttumiseen. Lannoitus sekä maanparannusaineiden kuten kalkin ja kivennäismaan lisäys aikaansaavat yleensä sen suurenemisen. 